\section{B A Institute of \\ YK Business Administration \\ 六下 \\ Karachi \\ Leadership and Ideas for Tomorrow}

Business Review

Volume 2 Issue 2 July-December 2007

7-1-2007

\title{
Conflicting paradigms: Alternative Islamic approaches to some business ethics
}

Javed A. Ansari

College of Management Sciences PAF-Karachi Institute of Economics and Technology, Karachi, Pakistan

\section{S. Zeeshan Arshad}

Shaheed Zulfikar Ali Bhutto Institute of Science and Technology, Karachi, Pakistan

Follow this and additional works at: https://ir.iba.edu.pk/businessreview

Part of the Business Law, Public Responsibility, and Ethics Commons, Human Resources Management Commons, Islamic Studies Commons, and the Marketing Commons

\section{(c) (i)}

This work is licensed under a Creative Commons Attribution 4.0 International License.

\section{Recommended Citation}

Ansari, J. A., \& Arshad, S. Z. (2007). Conflicting paradigms: Alternative Islamic approaches to some business ethics. Business Review, 2(2), 104-121. Retrieved from https://doi.org/10.54784/ 1990-6587.1392 


\title{
ARTICLE
}

\section{Conflicting Paradigms: Alternative Islamic Approaches to Some Business Ethics Discourses}

\author{
Javed A. Ansari \\ College of Management Sciences \\ PAF-Karachi Institute of Economics and Technology, Karachi, Pakistan \\ S. Zeeshan Arshad \\ Shaheed Zulfikar Ali Bhutto Institute of Science and Technology, Karachi, Pakistan
}

\begin{abstract}
This paper contrasts orthodox and revisionist Islamic approaches to an evaluation of ethical issues related to capitalist marketing, employee management relationships and finance. It argues that while the orthodox Islamic ethical paradigm is fundamentally oppositional to capitalism revisionist discourses provide an Islamic legitimation of capitalist order and can provide an ideological framework for subsuming Islamic economy and society within global capitalism.
\end{abstract}

\section{CONTRASTING ORTHODOX AND REVISIONIST APPROACHES.}

$\mathrm{T}$ is important to distinguish between two major currents in contemporary Islam with regard to business ethical issues. Orthodox ulema base their analysis on perspectives originating in the work of Imam Ghazali, Imam Ja'afar al Sadiq and Imam Ibn-i-Taimiyyah. They present Islam as a complete closed system seeking universal domination (Qutb 1979). Revisionist ${ }^{1}$ scholars reject the view that Islam is a system (Usmani $1991 \mathrm{p} \mathrm{17)}$ ) and argue that there is essential compatibly between Islamic and Modernist life worlds (Khurshid Ahmad 1979). Islamic revisionist scholars accept capitalist ${ }^{2}$ order as natural and rational. They advocate a selective reform of capitalist regulatory procedures and transaction forms and argue that such reform can reflect Islamic values within capitalist structures (Usmani 2002 Chap1).

The orthodox ulema on the other hand describe capitalism as jahillya ${ }^{3}$ (Qutb $1979 \mathrm{p}$ XIV). In this view the quest for freedom, autonomy and self creation are irreconcilable with suneuder to God's will (Ibadat) which must have both a public and a private manifestation. Therefore capitalist virtues such as self interestedness, this worldliness, toleration, instrumental rationality etc must be suppressed for they promote human autonomy and freedom and trivialize the quest for God's love and submission to His will (Maududi 1967 p 79). The economy is a sub-system of the complete and closed Islamic system focused on Ibadat and the Islamic economy can 
have no existence outside this systemic whole (Maududi 1953 p 17-19). It cannot be integrated with or subordinated to capitalist order since the self which flourishes in capitalist order lacks the ethical qualities - self denial (zuhd) and self annihilation $\left(f a^{\prime} n a\right)$ - which characteristise Islamic individuality. In this perspective ethical growth ( $m a^{\prime}$ arafa) is the continuing rejection of self interestedness and self determination and the limitless immersion of the self in God's love. Ethical knowledge is not obtained by reason, intuition, desire or experience but through revelation in Islamic scripture and history and this knowledge provides the sole source for the derivation and application of ethical principles within the economy (Qutb 1979 p 43 - 52).

Revisionist authors on the other hand argue that Islamic virtues can flourish in capitalist order. They explicitly endorse the natural philosophy which underlies Smith's conception of Political Economy. "There are many natural laws operative in the universe, the law of demand and supply is one such law" (Usmani 1991 p27). This leads Usmani to an unqualified acceptance of Smith's conception of the inevitable harmony in the pursuit of individual interest and social well being ${ }^{4}$. Usmani justifies the determination of values on the basis of revealed preferences and explicitly rejects the need to subject preferences to moral evaluation (Usmani $1991 \mathrm{p}$ 32 - 33). Therefore in Usmani's view "the basic philosophy underlying capitalism is correct in that it identifies the law of supply and demand and the profit motive as the mechanisms for addressing the fundamental economic problem of scarcity because this reflects natural human properties" (1991 p 35) ${ }^{5}$. Since the Shariah, according to Usmani, has given no explicit injunction requiring a Muslim to always prefer gain in the Hereafter therefore the determining principle with reference to the allocation of resources will be utility / profit maximization (Usmani 1991 p36).

Islamic revisionists seek the incorporation of Muslim economies within global capitalism. "Islam's main concern is in encouraging economic development with social justice" (Khurshid Ahmad 1991 p226). Tazkiah and falah are interpreted as "the optimization of human well being" "(Khurshid Ahmad 1979 p 231) ${ }^{6}$. Islamic revisionists see the Shariah as a means for articulating the self interest of the citizens of capitalist states and not as a repudiation of capitalist practices. In their view the Shariah requires a restructuring (not a deconstruction) of capitalist transaction forms and regulatory procedures ${ }^{7}$. Such a restructuring reforms and strengthens capitalist order $^{8}$. As we shall see in sec IV Islamic banking is justified on the grounds that it accelerates the rate of capital accumulation.

The following sections seek to explicate differences in the orthodox and revisionist Islamic approaches to an evaluation of capitalist (business) ethics in marketing, the management employee relationship and finance. 


\section{ISLAMIC RESPONSES TO THE ETHICS OF CONSUMPTION AND MARKETING}

Orthodox Islam rejects the maximization of utility (the pleasure principle) as an objective of consumer behavior. Imam Ghazali defines reason ( $a q l)$ "(as) a means for obtaining knowledge of what God has commanded and of what he has forbidden and a means for winning His favor .... (a) knowledgeable person (aqil) has the ability to forgo pleasure as he can discern the consequence of his acts. Pleasures do not motivate him or determine his acts" (Ghazali n.d. Vol1 p167). In the orthodox view reason is not an instrument for self fulfillment and of expansion of the realm of freedom but of self denial and submission to God's will. Rationality is thus a means for rejecting self determination in the market as elsewhere.

In the orthodox view the rejection of autonomy and surrender to God's will requires a necessary sacrifice of welfare ${ }^{9}$ in this world, therefore orthodox Islam (like Catholic Christianity) regards poverty as a cherished virtue and recommends curtailment of needs and minimization of consumption. In Islamic order the most preferred form of consumption related expenditure is infaq ${ }^{10}$ (Ghazali n.d. Vol 11 p248) and its purpose is to win God's pleasure. Imam Ghazali explicitly condemns pleasure (shahwat) as an objective of consumption. "Pleasure is the means through which the devil captures the hearts of men. Filling one's stomach even by halal and pure food is a means for allowing the devil to enter the heart for a filled stomach incites men to seek pleasure and pleasure is a weapon wielded by the devil" (Ghazali n.d. Vol III p62). He goes on to condemn affluent appearance in clothing, furnishing, dwelling and means of transport. "The devil inflames desire ... Desires are inherently insatiable and ultimately destroy faith (iman)" (Ghazali n.d. Vol III p $67)^{11}$. Iman Ghazali writes "The stomach is the source of all desires It is the desire for consumption which generates the lust for wealth. If men discipline the self through hunger they will not revolt against God" (Ghazali n.d. Vil III pl16-117) ${ }^{12}$.

Orthodox Islam seeks a minimization of consumption. "Expanding consumption is a major cause of economic injustice. Islam has banned all forms of consumption which harm morality such as speculative transactions, manufacture and sale of intoxicants, music and its related arts, the sex industry, the sale of (men's) silk garments, ornaments and gold jewellery, photographic products etc. If the prohibitions and sanctions of Islam are observed there will remain no scope for luxurious and ostentatious consumption and men will have to adopt a modest standard of living" (Maududi $1963 \mathrm{p} \mathrm{17})^{13}$.

Imam Ghazali lists six principles of marketing in the Ahya (Vol II p 141 - 146). "The merchant must enter the market to enjoin good and forbid evil - the time spent (on market transactions) should be strictly limited and the manufacturer, the merchant and the customer must continue to hymn the praises of God while engaged in the transaction, the merchant must avoid the vices of avarice and covetousness, he 
should limit his desire for profit. He should limit his consumption and close his shop as soon as he has earned enough to satisfy his need" (n.d. Vol III p 142). Imam Ghazali lays particular stress on the need to maintain low prices (n.d Vol III, p 174 176) and describes the function of the muhtasib (the government appointed controller of prices in considerable detail (n.d. Vol I Chap 7 and 2004 p $316-319$ ).

Traders are exhorted not to stock commodities to raise prices. They should seek to minimize profits. They should avoid advertising their products ${ }^{14}$ and ensure that the deal struck with the customer reflects a spirit of Islamic justice $(\mathrm{adl})$ and munificence (Ihsan) (Ghazali 2004 p 200 - 206).

The orthodox Islamic view rejects capitalist market practices. It argues for limiting consumption and regards the purpose of marketing as the fulfillment of religious obligations. It advocates minimization of profits and rejects competitive behavior. It legitimates state regulation of the market to maintain low prices. This is very similar to the original Catholic Christian discourse on trade practices ${ }^{15}$.

On the other hand Islamic revisionists seek a legitimation of capitalist market practices. "Islam does not deny (the efficiency and legitimacy of) market forces. The profit motive is also acceptable" (Usmani $1999 \mathrm{p} \mathrm{17)}$ ). Capitalism is criticized not for the ends it sets itself - utility / profit maximization - but for "creating monopolies which paralyze market forces" (Usmani 1999 p 17). The utility maximizing objectives of the market are fully endorsed. "The mission of the Holy Prophet (SAW) include(s) the fostering of the good life, welfare provision, alleviation of hardship, (and) generation of prosperity" (Chapra 1979 p197). Since the Islamic state is said to have an obligation to maximize welfare, spirituality effectively collapses into material practices. "Working hard for material well being is as spiritual as the

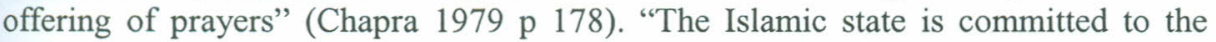
satisfaction of the material needs of all people" (Chapra 1979 p 200) without constraining market freedom ${ }^{16}$. Freedom is a central value for Islamic revisionists. "Islam has incorporated within its economic system the essential elements of free enterprise, private property and the market mechanism. The profit motive has also been upheld" (Chapra 1979 p 216). While Islamic revisionists accept that Islam imposes some constraints on utility / profit maximizing behavior (Usmani $1999 \mathrm{p} \mathrm{18)}$ they insist that the acceptance of these constraints is necessary for long run utility maximization - the revisionists are thus advocating the acceptance of these constraints on rule utilitarian grounds ${ }^{17}$. The Islamically structured market is expected to generate higher levels of utility and profit than contemporary capitalist markets (Chapra 1993 p 113 - 116).

The technical writings of Islamic revisionists define the consumption function in a typical Keynesian manner (Taher 1992). The theory of demand is fully endorsed for non haram products (Siddiqui 1996 p 36 - 40) as are conceptions of marginal utility, elasticity, equilibrium etc (Siddique 1996 Chap 1 - 3). Taher (1992 p 161 - 166) also 
endorses rational choice theory with minor modification ${ }^{18}$. The list of products the consumption of which is considered by Islamic revisionists to be forbidden (not subject to the law of supply and demand) has been getting shorter over time. Thus many financial products - specially money market derivatives - originally regarded as unacceptable are now regarded as legitimate (Usmani 2002 p 114 - 116). Electronically transmitted photographs have also been legitimated.

Thus limitations placed on consumption by Islamic revisionists would be acceptable to mainstream communitarian thinkers such as MacIntyre, Taylor and Rorty who may regard them as necessary means for sustaining identity consciousness and community solidarity ${ }^{19}$. In the expanding non prohibited sphere the Islamic economy should, in the revisionists view operate as a collective of perfectly competitive markets. Price fixation by the state is strongly condemned and fair prices are expected to be generated through general equilibrium processes (Ahmed $1995 \mathrm{p} 121$ - 123). A system of perfectly competitive equilibrating markets is expected to achieve distributive justice and guarantee capitalist rights endorsed by both neo liberals such as Nozick and Hayek and by revisionist Islamic authors (Ahmed $1998 \mathrm{p}$ $119-127)$.

Yusuf (1993) has summarized the views of the Islamic revisionists on what the Islamic state cannot do with respect to market regulation.

- It cannot mandate a monopoly price structure ${ }^{20}$.

- It cannot levy custom duties and impose quantitative restrictions or consumption taxes.

- It cannot impose exchange control

- It cannot levy income tax or any tax for the protection of industry.

- It cannot levy indirect taxes.

In this perspective the Islamic state is a minimalist Nozickian state. Its central value is freedom. The consumer and the trader are not restrained and market regulation is limited to the control of practices and products explicitly forbidden by the Shariat. ${ }^{21}$. Revisionist Islamic thinkers reject the values of Zuhd and Faqr as operative principles in the market. Revisionist Islamic scholarship dominates the disciplines of Islamic Economics and Islamic Finance which have flourished under Saudi sponsorship since the 1970 s - a period when luxurious living, indulgence, opulence and extravagance have become characteristic of the Saudi life style. The teachings of revisionist Islam can easily be accommodated ${ }^{22}$ within mainstream market ethics for the revisionists endorse utility maximization and the determination of prices through market equilibrium. 


\section{THE ISLAMIC EVALUATION OF THE CAPITALIST EMPLOYMENT CONTRACT}

In the orthodox perspective the objective of both the employer and the employee should be the fulfillment of one's obligations towards one's dependents and earning merit for life hereafter (Ghazali 2004 p 200). Seeking wealth for pleasure and for accumulation are condemned (Ghazali 2004 p 201). Labour is a means for saving one self from the fire of Hell and the Prophet described the manual laborer as God's beloved (Ghazali 2004 p 221).

Imam Ghazali recommends that economic activities should be restricted to four sectors: agriculture, textile, construction and administration (including defense) and to the production of the inputs of these four sectors (Ghazali n.d. Vol I p 50 - 54). This restriction on the sphere of production and distribution emerges from orthodox Islam's commitment to reduce needs (Ghazali n.d. Vol I p $143-147$ ) ${ }^{23}$. Men's participation in economic activity ${ }^{24}$ should be subordinated to their religious activities. In traditional Islamic society employment for gains (self employment and employment for others) is a marginal social activity (Rodinson 1972 chap 6). Gainful employment is a means for the achievement of the maqasid-i-Shariah and for avoidance of dependence on others (Ghazali n.d. Vol II, p 111 - 112) "Business should not be (established) for the purpose of the accumulation of wealth... If the intention of (establishing) business or (entering into) employment is accumulation this is condemned by the Shariah. Gainful labour should be limited to the time it suffices for the fulfillment of needs" (Ghazali n.d. Vol II p $144-145)^{25}$. Imam Ghazali recommends gainful employment for no more than two days per week between Ishraq and Zuhar prayers (about 6 hours) for the fulfillment of such needs (Ghazali n.d. Vol II p 145).

Employment should be rejected in haram (forbidden) and mushtaba (doubtful) professions. It is not permissible to enter into employment contracts in industries involving speculation, interest or exploitation (Ghazali n.d. Vol II p 147). Working for an un Islamic government - a government not implementing the Shariah - is also forbidden (Ghazali n.d. Vol II p 147) as is employment for the purpose of enhancing one's standard of living ${ }^{26}$.

Working for capitalist business - business established for maximizing share holders value - is not permissible according to the orthodox Islamic view for the capitalist employment contract subordinates labour to a management which is legally obliged to maximize profit as an end in itself (Bakan 2004 Chapter 2). Entering capitalist employment is therefore not permissible according to Shariah law in the view of the orthodox Islamic ulema who also forbid employment in the capitalist public sector and in money and capital market transaction (Jama'at-I-Islami 1949, p 17-74) ${ }^{27}$. 
Some orthodox writers (Banna 1984, Hussaini 1973) argue that Islamic trade union organization is a necessity within capitalist order. Hussaini (1973, p $11-24)$ argues that Islamic trade unions under the leadership of the ulema can develop into resistance mechanisms struggling for a transcendence of capitalist relations of production and exchange. The Islamic trade union should not seek codetermination of wages and working conditions nor seek collaboration within corporatist state structures ${ }^{28}$. It should struggle to delegitimise and deconstruct the capitalist property form. It should work for the dissociation of the enterprise from the capital and money markets. Hussaini's (1973 p 78 - 86) arguments for the dissolution of the capitalist property form are alien to Industrial Relations (IR) and Human Resource Management (HRM) discourses both of which accept the legitimacy of capitalist property and regard it as non transcendable ${ }^{29}$. Transcendence from capitalist order is unethical within the IR / HRM paradigms because it violates a fundamental human right - the right of property - and amounts to what Locke calls "a civil war" against constitutional representative democracy (Locke 1963 p 175 - 9).

On the other hand revisionist Islamic writers accept the capitalist property form as legitimate. The underlying paradigm in Islamic revisionist social analysis is Neo Classical Economics. As Nejatullah Siddiqui writes "(C)onventinal economics, remains (important because) private property, free enterprise and competition have not been rejected by us. They have only been complemented" (Siddiqui 1996 p 61).

The profit motive and the utility function "have been diluted, not abandoned" (Siddiqui $1996 \mathrm{p} \mathrm{9).} \mathrm{The} \mathrm{revisionists} \mathrm{seek} \mathrm{"the} \mathrm{humanization} \mathrm{of} \mathrm{economics"}$ (Siddiqui $1996 \mathrm{p} \mathrm{9).} \mathrm{This} \mathrm{would} \mathrm{be} \mathrm{regarded} \mathrm{as} \mathrm{admirable} \mathrm{by} \mathrm{many} \mathrm{welfare}$ economists, most Social Democrats and all followers of Kant and Rawls.

The Islamic revisionists accept "the primary importance of a market economy with private property and freedom of contract" (Siddiqui $1996 \mathrm{p} \mathrm{12}$ ). They envisage the determination of the wage rate within a system of general equilibrium for equilibrium prices "(are) the prices at which the amounts willingly supplied and demanded are equal: No other prices should rule in the labour market or else where" (Siddiqui 1996 p 15). "The free market economy is (a system) tending towards an efficient and equitable allocation of resources". (Siddiqui 1996 p 17). Siddiqui (1996 p 19 -23) fully endorses neo classical labour market analysis. Marginal productivity theory is accepted: Wage flexibility is considered to be desirable and market rigidities are deplored. However a high wage policy without the introduction of market distortions is also advocated on social democratic grounds. This is not seen as inconsistent with the systematic determination of wages on the basis of the marginal productivity principle (Siddiqui 1996 p 21). Labour is also exhorted to accept a wage lower than marginal productivity to avert capitalist crises (an advocacy of incomes policy). 
Collective bargaining is seen as a means for permuting cooperation between labour and management. Conflictive labour struggles are strongly condemned and there is of course no room for the transcendence of capitalist employment contracts. (Siddiqui 1996 p 21 - 24).

According to Chapra, the Prophet is supposed to have established "a welfare state" (Chapra 1979 p 176). But like the Keynesian state, "Islamic welfare state is not a police state... It accords primary value to individual freedom" (Chapra $1996 \mathrm{p} \mathrm{199)}$. Therefore interfering with the labour market is legitimate only if it is concerned with correcting market failure and institutionalizing regulatory procedures which can be justified on rule utilitarian grounds. Essentially the Islamic Welfare State plays an educational and a mentoral role within the market and this revisionist perspective is very close to ideas presented by a host of social democratic writers - from J.S. Mill, Hobhouse and Weber to Tawney, Giddens and Rorty (Callinicos 1999 passim).

Thus the employee is entitled to a "just wage" but this just wage is truly just only when it is determined by marginal revenue productivity (Siddiqui 1996 p $20-21$ ). It should be sufficient to fulfill basic needs (Chapra 1997 p 200). Conditions of work "should not be so miserable that the laborer's efficiency declines, health deteriorates (and) ability to enjoy income is impaired" (Chapra 1979 p 207).

"Islam also protects the employers by placing certain obligations on the employees (particularly) diligence and efficiency. The Islamic state should promote these work ethics and provide vocational training" (Chapra 1979 p 207). Although a fair distribution of income is a legitimate policy concern of the Islamic Welfare State this is expected to be an unintended consequence of the implementation of Shariah laws (Chapra 1979 p 210 - 211).

Neither Chapra (1979) nor Khursheed Ahmed (1979) focus upon the role of collective bargaining and trade unions in the determination of a floor wage and working conditions. There are relatively few papers on union rights and labor representation issues in the voluminous literature produced in Islamic economics journals and prepared for conferences in this area. However a major study representative of the mainstream revisionist view notes that:

"The foremost duty of the ruler is to provide employment to every able bodied and willing person. Furthermore the state must make such arrangements as to provide relief to the laborer from distress and to invest him with real bargaining pewer. Otherwise he will find himself constrained to undersell his labour power. This of course is not compatible with freedom and mutual consent which are the prerequisite for any contract to have full legal effect" (Ahmed 1995 p 131 - 132).

Revisionist thinking is thus capable of accommodating trade unionism. This was stressed during the 1970 s but with the advent of globalization and widespread policy 
liberalization the emphasis has shifted and revisionist Islamic discourse has been shaped to justify HRM practices and procedures. Nevertheless trade unions willing to accept subordination to management authority and to act as instruments for the execution of management constructed strategies can be easily accommodated within the revisionist Islamic reformulation of HRM discourse and practice (Ansari 2001).

\section{ISLAMIC ASSESSMENTS OF THE LEGITIMACY OF FINANCE}

In capitalist order it is the act of exchange which ascribes and is a means for the realization of value to an activity and to a commodity ${ }^{30}$. Capitalist money is the universal equivalent of exchange value and is therefore dedicated to accumulation. It goes through production only in order to increase its own quantity. When money is used for any other purpose it leaves the circuit of (capital) accumulation and is therefore no longer capitalist money. When money is within the circuit of accumulation it represents the exchange value of all commodities in circulation and it also represents expectations about the exchange value of commodities expected to enter into circulation in the future.

It is this dual character of capitalist money which allows finance to dominate production in civil society. Capitalist credit i.e. bank credit is a means for converting non capitalist money into capitalist money, a means for accumulation. It is the growth of interest bearing deposits which makes possible the conversion of noncapitalist money into capitalist money. It is in this sense: that "(I)nterest is the lifeblood of capitalism" (Maududi 1963 p 9). Finance is particular to capitalist order. It is a combination of capitalist money, capitalist credit (bank credit) and capitalist property (equity capital). Finance determines / assigns value to all market practices on the basis of their contribution to capital accumulation. The cost of capitalist credit, interest, and the value of capitalist equity, share prices, are determined on this basis in financial markets (Ansari, Naeem and Zubairi 2005 p 15 - 19, Meszaros 1995 p $134-160)^{31}$.

Orthodox Islam rejects both interest (riba) and the speculative determination of asset and commodity values (gharrarr). Arguments for rejecting interest and speculation presented by the orthodox ulema are broadly similar to those developed by Christian scholastics (see Maududi 1960, 1963 and Tawney 1949 Chapter 2). There is in orthodox Islamic discourse a more explicit rejection of the capitalist property form. Capitalist property is the dedication of all economic endeavor (utilization of labor, wealth and natural resources) to accumulation. Imam Ghazali explicitly rejects accumulation as a legitimate objective of economic endeavor ${ }^{32}$. He writes "The person who dedicates himself to accumulation is cursed, the real objective (of business) must be salvation" (2004 p 200). "He who busies himself in seeking worldly gains and forgets the Hereafter is cursed. Accumulation cannot be a means for salvation. Man's wealth (doulat) in the world is his religion. Man must avoid professions which do not serve man's real needs and the products of which are mere 
ornaments and luxuries. All professions in which there is a possibility of interest transactions should be scrupulously avoided, as also professions, which may involve speculative transactions. The brokerage profession, should be avoided (on this basis). (A) significant proportion of the day should be devoted to worship in the mosque and the duration of business should be restricted and specially avoided in the mornings and evening... (He) who enters the market merely to serve his worldly needs, he will not achieve his real objective (i.e. salvation). One must not undertake travel for satisfying avarice and covetousness. One must leave the market as soon as one has earned enough to satisfy (one's) needs. One (should) not engage (in business) for more than two days a week" (2004 p 221 - 224).

"Competitiveness is born of malice. Competition destroys (mankind). The Prophet (SAW) has said "competitiveness destroys virtues as fire destroys wood" He (SAW) has said "you cannot enter Paradise without faith and competition destroys faith" (2004 p402-403).

"The love of capital ( $\left.m a{ }^{\prime} a l\right)$ is a great calamity (fitna). The Prophet (SAW) has said "the love of capital and fame nurtures hypocrisy as water nurtures crops" and further "two hungry wolves do not destroy a flock of sheep as the love of capital and fame destroys faith" and further "there will appear after me a group of people who will eat a variety of delicious food, wear fine clothes, lust after beautiful women and ride splendid horses. They will not be content even with abundance. They will worship the world and dedicate their effort to it. I am Muhammad and I order you that if your children see such people they should cut of all relations with them... anyone who maintains relations with (this group) will join this group in destroying Islam" and further "abandon this world for the worldly because taking (from it) more than you need will destroy you. Man always says my capital, my capital, (but) you have nothing except that which you eat and that which you wear and that which you store in the Hereafter by spending in the way of God" (2004 p $414-415)$.

"Capital ( $m a$ 'al) opens the door for vices and God's disobedience and exacerbates and inflames desires and lust, the owner of capital will not be able to avoid luxurious living. Contentment ( $\mathrm{Sabr}$ ) becomes alien to him. He seeks to build paradise on earth. (The love of capital) incites him to seek the favor of corrupt rulers and this nurtures many vices, covetousness, pride, vanity, lust for pleasure. Capital becomes a veil which restrains man from absorbing his being in the love of God" (2004 p 418 -419).

Orthodox Islamic teaching thus rejects both maximization of pleasure and maximization of the rate of capital accumulation as legitimate economic objectives. "Economic malfunctioning arises from the systemic dominance of self interestedness. The economic elite has (become) obsessed with selfishness, covetousness, lust and avarice. The devil induces them to accept the view that the resources they possess should be used either for pleasure maximization or for accumulation. 
'A massive growth in need and in accumulation for its own sake (fuel) economic injustice and malpractice. Accumulation feeds avarice and covetousness and deprives the poor of resources to satisfy their basic needs.

'It is in principle wrong to focus economic activity on accumulation. Accumulation occurs through interest based transactions or through investment in trade and industry. Both these methods intensify class differences in society and exacerbate class antagonism.. Concentration of power and wealth increases and this creates conditions of crises for there is chronic over production and under consumption (within the system)" (Maududi 1961 p $10-12)^{33}$.

Maududi goes on to identify the compulsion to accumulation as the main cause of cyclical downturns, the occurrence of socio-economic crises and intensified international conflicts. In his view the establishment of a virtuous and just economic system requires the rejection of capital accumulation as an objective of economic activity (1963 p 17-20).

There is thus no room in orthodox Islam as there is not in Catholicism and Orthodox Christianity, for a legitimation of finance and of financial markets. Finance is specific to capitalist order and alien to religious society. Finance cannot exist outside capitalism and as orthodox Islam claims to be a complete closed system (not a mere Habermasian life world) therefore it comprehensively rejects all financial norms, transaction forms and regulatory procedures. Issues raised with respect to the justification of these norms, regulations and transaction forms - investment ethics accounting standards and disclosure, corporate governance, corporate law, insider trading, - are alien to orthodox Islamic discourse for this discourse rejects the validity claims of finance and of capitalist order as a whole.

On the other hand neither capitalism nor finance are rejected in revisionist Islamic discourse, As we have seen above Taqi Usmani regards capitalism to be a natural not historical - order (Usmani 1991 p 22 - 23). Both Nejatullah Siddiqui (1996) and Taqi Usmani $(1991,1999)$ endorse the Islamic legitimacy of a range of financial assets - shares, bonds, derivatives, deposit and investment accounts held at Islamic banks, Islamic equivalents of insurance contracts and of forward contracts, Islamic money market equivalents etc. Speculation as a determinant of both money and capital market transactions is also accepted as legitimate (Siddiqui 1996, p $46-47$, Usmani 1991 p 72 - 76). Options and commodity forward and future transactions are also endorsed (Usmani 1991, p 74 - 76). Financial markets are seen as serving necessary functions for the achievement of Shariah endorsed purposes. Capitalist order is fully endorsed by Usmani who legitimates corporate personhood and the principle of limited liability (1991 p $79-82)$.

While there is a frequent rhetorical condemnation of interst, the Islamic banking and finance movement "recognize(s) the time value of money as understood in 
contemporary financial theory" (Henry and Wilson 2004 p 2). Many interest equivalents have been invented for both money and capital market transactions, the most widely used one being murabaha (mark up financing) which accounts for over two thirds of financing by a typical Islamic bank. Each of the 200 or so Islamic banks which are members of the Geneva based International Association of Islamic Banks (IAIB) is supervised by a Religious Advisory Board comprising of revisionist ulema. The Board scrutinizes and endorses the Shariah compliance of each money and capital market transaction of each Islamic bank.

Monzer Kahf has described the Islamic finance movement as "the rise of a new power alliance of wealth and Shariah scholarship" (Kahf 2004 p 17). Revisionist interpretations of Shariah constraints on financial transactions have become more and more liberal over time with a near universal acceptance of the legitimacy of fixed rates of return on loan and equity transactions. Islamic finance flourishes in liberalized markets. "The growth of Islamic finance has been seen as" partly a consequence of privatization and de-regulation" (Warde 2004 p 40 - 41) and there has been significant capital flight from Muslim countries to the West (estimated at over $\$ 10$ billion in the late 1990s by Wilson 2004 p 129) through Islamic managed funds alone. Saeed-al-deen Ibrahim sees the Islamic financer as "a cultural broker par excellence between the West and the Muslim World" (1982 p8). Empirical research has shown that the performance and behavior patterns of the typical Islamic customer is not significantly different from that of the Western investor although some similarities have been noted between the Islamic and "ethical investors" - both seek maximization of return within constraints such as in the case of the Islamic investor not putting money in interest bearing transactions, in Israeli and Jewish corporations, and in firms producing or distributing alcoholic beverages and pork. Marketing strategies targeting both Islamic and ethical investors typically use moral suasion and stress religious and social benefits of their financing programs rather than simply private returns (Warde 2000 p 155 - 156). Usmani's analysis of Islamic investment behavior presented to a European audience in 2002 (Usmani 2002 p 93 101) does not add (or subtract) any thing to the mainstream discussion of investment behavior. No objections have been raised by the revisionist ulema or Islamic economists to capital flight (e.g. Chapra 2000) while discussing the East Asian crises of 1997 - 1998. Quite the contrary they stress the illegitimacy of imposing constraints on the movement of capital across national borders (Usmani 2002 p 94).

Fundamental differences between capitalist and Islamic presumptions regarding human behavior and social and individual norms (succinctly contrasted for example by Zahid Siddique. 2005 p 121 - 125) are ignored by advocates of Islamic finance and their discussion of ethical issues raised by financial practices adds little to mainstreams ethical discourse. Thus Mushtaq Ahmed (1995) a typical Islamic revisionist author does not distinguish between Islamic and capitalist conceptions of ownership and his analysis of fraud, unjustified appropriation, merit based remuneration systems, invalidation of partnerships (charter revocation) deferral of 
wages and financial dues, price fixation, hoarding, monopoly, protectionist measures and coercion (1995 p $112-125)$ is virtually indistinguishable from that of typical mainstream Business Ethics authors such as Velanquez (1997) or Stuart (1996). Ahmed does of course condemn riba (1995 p 104 - 108) but this is inconsequential for as we have seen the Islamic finance movement which enjoys the support of the revisionist ulema has developed a large and rapidly widening range of interest equivalent financial contracts. We may conclude that in the revisionist perspective Islam is a lightly modified version of capitalist order. The difference betweens American and Swedish capitalism are more pronounced then the difference between Islamic and American capitalism. As we have seen above (and elaborate in Meenai and Ansari 2004 Chapter 16). Islamic finance and Islamic economics are projects sponsored by the Saudi Arabian government and by multinational financial agencies particularly the IMF and the World Bank. It is not surprising therefore that the moral discourse of Islamic finance replicates the themes of mainstream Business Ethics in this area.

\section{CONCLUSION}

Islamic revisionist scholarship provides a framework for the legitimation of capitalist norms, procedures and transaction forms within the context of an Islamic ethical discourse ${ }^{34}$. It can therefore play a similar role in capitalist legitimation as that played by Protestantism in the early modern period. On the other hand orthodox Islamic discourse on consumption, employment relations and finance is uncompromisingly oppositional to capitalist order.

\section{REFERENCES:}

1. We define Islamic revisionism as the reinterpretation of Islamic scripture, traditions and historical consensus (ijma) to establish traditional Islam's essential compatibility with modernist epistemology and praxis. Islamic revisionism is an Islamic justification of modernist discourse and should be differentiated from Islamic modernism, which is a modernist interpretation of Islamic discourse. In the Indo - Pak subcontinent the Islamic revisionist movement is dominated by the thought of Maulana Ashraf Ali Thanvi. Thanvi was a khalifa of Sheikh Imadullah Muhajir Makki who was exiled to the Hejaz for establishment of a centre for armed struggle against the British in 1858 . Ashraf Ali Thanvi converted the Thana Bhavan centre into a seminary and produced a voluminous literature justifying Muslim acceptance of British rule. He apposed Sheikh Mahmud ul Hasan's insurrection (tahrik-e-rashmi roomal 1913 - 1916) and the khilafat movement (1919 - 1924) and was an important ideologue of the Muslim League. His principle khalifa Maulana Shabbir Usmani was the Muslim League's most prominent alim during the 1940s and 1950s 
Maulana Usmani played a pivotally curcial role in the Sarhad referendum of 1947. See Quraishi (1963) and Amin (1936).

2. We define capitalism as a social order dedicated to capital accumulation as an end in itself through the universal dominance of capitalist property and systems of financial valuation (Ansari, Naeem and Zubairi 2004 Chapter 2).

3. Best translated not as "ignorance" but as "savagery". (Pickthall 1952 p 56 - 59).

4. Usmani writes "Although every individual works for his own profit the natural laws of supply and demand force him to fulfill the need of society" (Usmani $1991 \mathrm{p} \mathrm{23).}$

5. Further "Islam fully endorses the profit motive and market forces as a basis for human behavior" (Usmani 1991 p 38 - 39).

6. Further "Development articulates two cardinal Islamic principles. First the optimum utilization of resources and secondly their equitable distribution" (Khurshid Ahmad 1979 p 232).

7. The most lucid expression of this stance is currently to be found in the work of Yusuf al Qardhavi's Wastanya School.

8. Thus Usmani argues that taking account of Shariah sanctioned halal and haram injunctions leads to the elimination of monopoly and to the strengthening of competitive markets (1991 p $46-47$ ).

9. i.e. of consumption for as Welfare Theory shows appropriately discounted consumption flows over specified time periods are the only available practical measures for estimating both individual and social welfare. See Little (1963 Chap 1 and 4).

10. Roughly the Islamic equivalent of the Christian conception of charity.

11. Further "Rejecting pleasure and suppressing desire is the sole way to reach God... Your self (nafs) is a constantly quarreling enemy against which you must wage perpetual welfare" (Ghazali n.d. Vol II p 111 - 112).

12. Further "(Necessities are only six; food, clothing, dwelling, household equipment, family and income .... More food should not be stored than that which suffices for a day... ( $t$ )he bread should be of coarse grain... The Prophet wore patched clothes and broken shoes. He rode on a donkey and (always) sat on the ground and said "I am a slave and eat like a slave and sit like a slave" (Ghazali n.d. Vol III p 353 - 354).

13. Maududi (1963 p $14-17$ ) is an adapted summary of Ghazali (n.d Vol III) p 111 - 124).

14. As this inevitably involves false description and exaggerated product quality claims (Ghazali n.d. Vol p 64).

15. There is astounding similarity in the views of Imam Ghazali and St. Francis of Assisi on market related behavior. One feels as if they had read each other's texts - a historical impossibility - and were providing fresh evidence to support each other's views. 
16. The Islamic welfare state as described by Khurshid Ahmad (1979 p 236 - 240) and Umar Chapra (1979 p 198 - 210) is a carbon copy of the Social Democratic, welfare state. Compare these texts with e.g. Giddens (1999).

17. Ansari (2001) assesses this argument in some detail.

18. Incorporating, altruistic concerns such as taking account of other people's needs.

19. Profits and utility are always maximized within social constraints - the Sabath is observed in Israel, Americans don't eat snakes etc.

20. Even if this is generated by a public monopoly which equalizes average cost and average revenue rather than marginal cost and marginal revenue.

21. As noted above, the list of restricted products and practices have been shrinking not only in financial markets but also with reference to the products of the photographic and image processing industries. This has important implications for advertising and entertainment businesses specially with reference to female culture and activity. However recent studies (Jalees 2006) have shown that advertising copy of Islamic banks outside Saudi Arabia is becoming increasingly similar to that of conventional commercial banks.

22. Advertising is acceptable and using the image of nude women and nude cardinals is unacceptable in both Saudi Arabia and Italy.

23. This has been discussed in Section II.

24. Imam Ghazali (n.d. Vol II p 146 - 147) recommends that women do not participate in economic activities baring exceptional circumstances.

25. As defined by Imam Ghazali see section II above.

26. "Such people become so absorbed in the company of women and the (consumption of) delicious food that they start living the lives of animals and forget the Day of Judgment" (Ghazali n.d. Vol II p 359).

27. Contemporary orthodox Islamic writers have written extensively on labour management in non capitalist business (businesses which do not transact with capital and money markets and which do not seek profit maximization). Such work is not discussed here because it explicitly rejects the whole capitalist system.

28. Involving the conception and administration of incomes policy.

29. Even radical IR advocates such as H.R. Clegg (1957 p 19 - 26) do not question the legitimacy of capitalist order but argue that unions should function as a permanent opposition within it.

30. This is of course a neo classical mainstream view contested by Marxists and neo Ricardian followers of Saraffa. For a classic review of this controversy see the papers in Sen (1970).

31. Both these views represent a departure from Hilferding's (2004) classic conception of finance capital.

32. See Section III.

33. Again a summary of (Ghazali n.d. Vol IV p $284-286$ ) with adaptations.

34. Grey (1999) has argued that capitalist order can exist within different sociocultural contexts and has distinguished between Anglo-American, Germanic and 
Japanese variants of capitalist order. Henry and Wilson (2004) argue that the Islamic fiannce movement represents an important moment in the historical development of a full blown Islamic capitalism - see specially their introductory and concluding chapters.

\section{REFERENCES}

Ahmad K and Ansari Z. (1999) Islamic Perspectives, Jeddah Saudi Publishing House.

Ahmed M. (1995) Business Ethics in Islam, Islamabad Institute of Islamic Thought

Amin M. Maulana (1936) Zaghoon Key Naseeboon Main Uqaboon Key Nasheman, Madrasatul Imadadia, Hyderabad (Deccan).

Ansari J. Naeem M. and Zubairi J. (2004) Financial Management in Pakistan, Karachi. Oxford University Press.

Ansari J. (2001) "Reading Islam aur Jadid Tijarat-o-Maeeshat": Pakisatn Business Review Vol 2 No 3 p $17-25$.

Ansari J. (2001) "HRM: Is Worker Resistance Possible" Pakistan Business Review Vol 2 No 4 p 3 - 17.

Bakan. J. (2004) The Corporation New York. The Free Press.

Banna H. (1984) Trade Unions: An Islamic Perspective ANN Arbor Islamic Publications

Callinicos A. (1990) Social Theory London Polity

Chapra U. (1993) Isalm and Economic Development, Islamabad, Islamic Research Institute.

Chapra U. (1979) "The Islamic Welfare State and its Role in the Economy" in Ahmad K and Ansari Z (1979 p 195 - 227).

Clegg H. (ed) (1957) Industrial Democracy and Nationalisation, Oxford, Blackwell.

Ghazali Imam (n.d) Ahya-al-Ulum-al Deen, Karachi Dar ul Isha'at (Translator Maulana Nadeem ul Wajdi) Urdu-Arabic text.

Ghazali Imam (2004) Keemiya-i-Saa'dat Lahore Maktaba-i-Rahman, (translator Muhammad Saeed ur Rahman).

Giddens A. (1999) The Third Way: The Renewal of Social Democracy, Cambridge Polity.

Grey J. (1999) False Dawn London, Granta

Hilferding R. (2004) Finance Capital New York Knopft

Henry C. and Wilson R. (2004) The Politics of Islamic Finance Karachi, Oxford University Press. 
Hussaini A. (1973) Trade Union Tahreek par Bhutto kay Mazalim Quetta. Jama'at-IIslam, Balochistan.

Ibrahim S. (1982) The New Arab Social Order, Boulder, Westview Press

Jalees T. and Fatima M. (2006) A Comparative Study of Islamic and Commercial Bank Advertising, Karachi PAF-KIET (unpublished).

Jama'at-I-Islam (1949) Roedad Vol IV Lahore Islamic Publications.

Kahf M. (2004) "Islamic Banks and the Rise of a Neo Power Alliance of Wealth and Shairah Scholarship" in Henry and Wilson (2004), p 23 - 58.

Khurshid Ahmad (1979) "Islamic Development" in An Islamic Framework" in Ahmad K. and Ansari Z (ed) p 223 - 240.

Little I.M.D (1963) Welfare Economics, Oxford Basil Blackwell

Locke J. (1963) Collected Works, Vol 6 Cambridge, CUP

Maududi A.A. (1960) Sood, Lahore, Islamic Publications

Maududi A.A. (1967) Islam aur Jadid Ma'ashi Nazaryat, Lahore, Islamic Publications

Maududi A.A. (1953) Islam ka Nizam-e-Hayat, Lahore Islamic Publications.

Meenai S. and Ansari J. (2004) Money and Banking in Pakistan, Karachi. Oxford University Press.

Meszaros I. (1995) Beyond Capital, London, Merlin

Pickthall. M. (1952) Islamic Culture, Lahore, Shaikh Muhammad Ashraf.

Quraishi I. H. (1963) Ulema In Politics, Karachi, Pakistan Historical Society and Royal Book Company.

Qutb S. (1979) Jada-o-Manzil, Lahore, Islamic Publications, (Urdu translation of Ma'alim fit Tareeq).

Rodinson M. (1972) Islam and Capitalism, London, Paladin.

Sen A. K. (ed) (1970) Growth Economics, Harmondsworth, Penguin.

Siddiqui M. Zahid (2005) The Political Economy of Neo Classical and Islamic Economics, Islamabad, Quaid-e-Azam University, M. Phil Dissertation, (Unpublished).

Siddiqui N. (1996) Teaching Economics In Islamic Perspective, Jeddah, King Abdul Aziz University

Stewart D. (1994) Business Ethics, New York, McGraw Hill.

Taher S. etal (1992) Readings In Microeconomics: An Islamic Perspective, Kaula Lumpur, Longmans 
Tawney R. (1949) Religion and the Rise of Capitalism, Harmondsworth, Penguin

Usmani T. (1999) Islamic Finance, Karachi, Idara tul Ma'arif.

Usmani T. (1991) Islam aur Jadid Tijarat-o-Maeshat, Karachi Dar al Uloom Karachi.

Usmani T. (2002) An Introduction to Islamic Finance, The Hague Kluver Law International.

Velauquez M. (1997) Business Ethics, New York, Prentice Hall.

Warde I. (2004) "Global Politics, Islamic Finance and Islamist Policies Before and After 11 September 2001” in Herry and Wilson (2004) 37 - 62.

Warde I. (2000) Islamic Finance in the Global Economy, Edinborough, Edinborough University Press.

Weber M. (1930) The Protestent Ethics and the Spirit of Capitalism, (translated by Talcot Parsons), London, Routledge.

Yusuf S.M (1991) Economic Ethics in Islam, Lahore, Sheikh Muhammad Ashraf.

"For most of history, earning a living was something you had to do because, after all, you had to eat. Life did not have that much leisure at all, in our sense of the word. Now, many people allow their work to consume their lives totally: that's what they enjoy. But in the past for people to admit that they enjoyed their work were simply - I wouldn't say it wasn't done - it wasn't expected ... the idea that your work was supposed to be meaningful was not a topic of discussion in the past. That's much different from today and even more different from the world of the future. Today more and more people simply expect and demand that their work and their jobs should be meaningful. I don't think it would ever have occurred to most peoples a hundred years ago."

Drucker, P.F. Managing in a Time of Great Change, p.295 